\title{
Climate change displacement and socio-economic rights of the child under the African human rights system The relevance of ETOs
}

\author{
Ademola Oluborode Jegede
}

\section{Introduction}

Climate change poses challenges to the populations of the world. Underlying the phenomenon is the increasing concentration of greenhouse gases resulting from anthropogenic activities which are pushing the climate beyond the level that is considered safe for livelihood (Intergovernmental Panel on Climate Change (IPCC) 2018; United Nations General Assembly (UNGA) 1988). This development has resulted in an increased warming of the earth surface which negatively affects societies and their populations (UN 2020; IPCC 2018). While climate change has several adverse effects on populations, displacement and its associated plight as consequence are significant for children in Africa. Importantly, how extraterritorial conduct or omissions associated with climate change can result in displacement of children in Africa merits scrutiny. Generally, extraterritorial obligations (ETOs) are a burgeoning topic in international human rights law (Vandenhole 2020; Bulto 2011). Hence, the extraterritorial link of climate change with displacement of children as both a challenge and driver of possible measures to address it in Africa is not as clear.

For instance, without a reference to displacement or ETOs, the UN Human Rights Council (UNHRC) Resolution 26/33 (UNHRC 2014), linking climate change to human rights, mentions only in passing that children are vulnerable to climate change. The subsequent report of the Office of the High Commissioner for Human Rights (OHCHR) connects climate change and the enjoyment of the rights of the child under the Convention on the Rights of the Child (CRC 1989) and highlights measures including 'extraterritorial jurisdiction' as a recommendation (OHCHR 2017, paras. 29 and 62(c)). Nevertheless, the basis for the application of such measures in the context of displacement of children in Africa is not articulated. Reports by Mbaye (2020), BBC (2019) and writings of other authors such as Boko et al. (2008) establish that states in Africa are more vulnerable to climate change. Also, the Committee on the Rights 
of the Child, the treaty monitoring body for the Convention on the Rights of the Child (CRC 1989), identifies climate change as a threat to children's health and urges states parties to put children's health concerns at the centre of their climate change adaptation and mitigation strategies (CRC Committee, General Comment no. 15), but this is done without any comments on extraterritoriality.

The extraterritorial nature of climate change is evident in its global nature (UNGA 1988) and climate pillar instruments such as the United Nations Framework Convention on Climate Change (UNFCCC 1992), and Kyoto Protocol (2005), and the Paris Agreement (2015) that recognise the global threat of climate change. For instance, the Paris Agreement (2015) draws no jurisdictional boundary in its call upon states to respect, promote and consider their respective human rights obligations towards the protection of the rights of the child and intergenerational equity when taking actions to address climate change. The nature of ETOs required of states in socio-economic and cultural rights context has been carefully expounded in the Maastricht Principles on Extraterritorial Obligations of States in the Area of Economic, Social and Cultural Rights (Maastricht ETO Principles 2011), and the authoritative writings including De Schutter et al. (2012). But, there is a rare scrutiny on the causal link of displacement of children to extraterritorial acts underlying climate change and its implication for their socio-economic rights in Africa.

Mutua (2000) defines the African human rights system by its normative instruments and jurisprudence. These normative instruments and jurisprudence reflect the efforts by Africa to respond to its own challenges by offering solutions to Africa's problems. Consequently, the children rights protection regime exists within the system, but the form of legal protection available to children in the context of displacement linked to climate extraterritorial conduct or omission requires an interrogation. For instance, there is the African Charter on the Rights and Welfare of the Child (ACRWC 1990) which prescribes a range of socio-economic rights for children. The treaty monitoring body of the instrument, the African Committee of Experts on the Rights and Welfare of Children (CERWC), nonetheless, has neither any jurisprudence nor major work on climate-induced displacement of children. Relevant activities around climate change have no specific focus on displacement. For instance, only a call for general awareness of the general impact of climate change is urged in a 2020 press statement where the CERWC reiterates that children are the most vulnerable to bear the brunt of the impacts of climate change in Africa (AU Press 2020). Resolution 153 (African Commission on Human and Peoples' Rights (ACHPR) 2009a) in relation to climate change in Africa is also not supported or informed by detailed analysis and bears nothing on extraterritorial link of climate change and displacement. A novel regional convention called the African Union Convention for the Protection and Assistance of Internally Displaced Persons in Africa (Kampala Convention 2009) recognises that climate change may occasion displacement in its Article 5(4); however, what this normative environment entails for the plight of climate-displaced children is neither specified in the instrument nor explained in the jurisprudence of the African Commission on Human and People's Rights (the African Commission), which is the treaty monitoring body for the African Charter on Human and Peoples (African Charter) (OAU 1986).

Against this backdrop, this chapter articulates the extraterritorial link of climate change to displacement and the socio-economic rights of children in Africa. It then explores how ETOs may be deployed under the African human rights system in response to the challenge. Some caveats are, however, necessary at the onset. First, the major focus of the chapter is not on the right to asylumseeking or refugee status which may or may not be the legal consequence of displacement. Displacement generally happens within a territory. Second, in dealing with displacement caused by climate change, it is acknowledged that even if differentially, scenarios causing climate change may occur within and outside Africa. These scenarios include population dynamics (Bongaarts and 
O’Neill 2018), historic fossil-based economic development path (IBRD and World Bank 2010), and the unsustainable consumption or 'way of life' of the North (Paris Agreement 2015, preamble; Mckibben 2003). However, in discussing displacement of children linked to climate change in Africa, emphasis is placed on the failure of states within and outside Africa to regulate the conduct or omission of non-state actors responsible for extractive activities and climate change response measures which may result in displacement of children abroad. Third, the focus on children is due to their vulnerability and dependent circumstance which, as shall manifest, may negatively impact their socio-economic rights. Lastly, while the plights of displaced children are certain, the contribution is exploratory in the sense that there is no present jurisprudence of the African human rights system on children's rights that either draws a linkage to climate change or specifically mandates the extraterritorial application of its instruments on the protection of children.

\section{The plight of climate-induced displacement of children and extraterritoriality}

The World Bank (2018) estimates that 140 million people will be internally displaced by slowonset climate change impacts by 2050. Of the 79.5 million displaced, the UNHCR (2019, p. 2) in its global report on forced displacement shows that 30-34 million are children. Due to circumstances including war and natural disasters, evidence exists that displaced children can cross national borders within Africa. Hence UNICEF (2018) highlights that 1/4 immigrants in Africa is a child, a development more than twice the global average. Of the African countries, South Africa and Nigeria host some of the largest child migrant populations in Africa (UNICEF 2018). Generally, the situations facing children substantiate unique challenges of displacement either at home or abroad. This is due to their vulnerability, reliance on adults and decreased ability to protect themselves from danger and to make decisions (Pfefferbaum et al. 2016). Displaced children lose the security, shelter, comfort, traditions and familiarity of a place and family which they have usually enjoyed. Where unaccompanied and separated from their parents, they are exposed to starvation and abuse in forms including trafficking, exploitation and violence (UNICEF 2018). This is not surprising in that displacement disrupts their access to necessities including food, water and sanitation, health and education (UNICEF 2018; UNICEF 2003). The plight of displaced children is not any different even where they are in the company of a displaced family. Loss of land and income that are associated with displacement often render parents and/or extended families incapable of providing for the necessities of children. When displaced outside their states, they need asylum protection and access to basic amenities that are often lacking in a foreign land (UNICEF 2018; UNICEF 2003).

Whether the displacement of children may result from effects of climate change linked to extraterritorial activities is the focus of this section. Extraterritoriality connotes the activities by a state outside its territorial borders (Kanalan 2018; Colangelo 2014). It contrasts generally with the traditional notion of human rights that regulates the relationship between the state and individuals within the territory of the states (Kanalan 2018). In the context of this paper, extraterritoriality encompasses the conduct or omission of a state linked to climate change within or beyond its territory that has effects of displacement on children. It raises a significant issue as to whether a state in Africa or beyond can be responsible for the climate-induced displacement of children and its threat to their socio-economic rights in another African state. This section demonstrates that this is possible in two ways: through the conduct or omission of an African state or its non-state actor in and outside its territory in Africa; and through the conduct or omission of foreign non-state actors from non-African states (developed states) in their territories and in Africa. 


\section{Conduct or omission of an African state or its non-state actor}

Emissions that are generated in African states and projects associated with alternative energy sources are significant to climate change, and arguably the displacement of children in Africa. To be sure, Africa accounts for only 2-3 per cent of the world's carbon dioxide emissions from energy and industrial sources; hence, it contributes least to climate change (UN 2006). This development is changing, though. In a new study featuring data compiled from two satellites, Japan's Greenhouse Gases Observing Satellite (GOSAT) and NASA'S Orbiting Carbon Observatory (OCO-2), Palmer et al. (2019) found that Africa's tropical lands released about close to 6 billion tonnes of $\mathrm{CO}_{2}$ in 2016. ACHPR (2019) and earlier writing of Gorte \& Sheikh (2010) explain that other carbon emission sources such as mining, construction and logging are a substantial driver of climate change in Africa. These findings are supported in more recent works. For instance, Burck et al. (2019) find that although Morocco has significantly increased the share of renewables over the past five years, its GHG emissions per capita are still high. The Mineral Council of South Africa (2019) and the Carbon Relief (2018) respectively account that due to its principal reliance on coal for energy, South Africa is adjudged as the world's 14th largest emitter of greenhouse gases (GHGs). Nigeria's $\mathrm{CO}_{2}$ emissions has increased through 1999-2018 period to end at 110.7 million tonnes in 2018 (World Data Atlas 2018a), while within the same period, there was an increase which ended at 2.9 million tonnes in 2018 in Democratic Republic of the Congo (World Data Atlas 2018b). Despite a noticeable decline in Egypt, at current level of 217.44 million tonnes, carbon emissions remain high (Y Charts 2020). The impact of these activities may not be directly responsible for the immediate state of the climate and displacement, nevertheless, it is beyond territorial boundaries of these states and will contribute its own share to the worsening of the climate everywhere including Africa. These emissions are linked to global warming which generate climatic problems, including heat waves, flooding, pollution and a rise in sea level, drought, flooding (Toulmin 2009) which by implication can trigger the displacement of populations including children in Africa.

Also, the pursuit of climate response measures by states in Africa such as alternative and renewable energy sources has extraterritorial implications for the displacement of populations including children. It occurs where a state-owned company in one African state embarks on climate response activities in another state which leads to expropriation of land belonging to families and thereby occasion the displacement of children belonging to such communities. To illustrate, a company based in South Africa, Sasol has projects in Mozambique that are allegedly linked with temporary or permanent loss of access to land and location of cultural significance such as graves, damage to public and private property, permanent physical and economic displacement of families including children (Globeleq 2015). STEG International Services, which is a subsidiary of the Tunisian State-Owned Company of Electricity and Gas (STEG), implements projects in other states in Africa including Sierra Leone, Tanzania, Rwanda and Democratic Republic of Congo (Concord Times 2020). Evidence from Rwanda shows that the activities of STEG have the potential for displacing populations including children (REG 2019). The fact that the activities of businesses can be conducted in this manner points at a lack of exercise of legislative control by the states in which the parent businesses are established in Africa.

\section{Conduct or omission of foreign-owned businesses of the North in Africa}

Climate-induced displacement of children linked to extraterritorial acts can arise from the failure of developed states to control effectively the conduct or omission of their private companies 
operating in states in Africa. In particular, the activities of companies of the North in the extractive sector during the mining process, as shown by reports, contribute greatly to the release of greenhouse gases such as carbon dioxide and methane which aggravate climate change (Bruckner et al. 2014). As reported by the UN Environment (2019), such extraction activities have been responsible for 18 per cent of resource-related climate change. The negative implication of this development on water resources, food security, biodiversity, human health and infrastructure triggers displacement of populations including children.

The lack of appropriate control by developed states can incentivise widespread expropriation of land for climate response projects by companies and thereby drive the displacement of children along with their families. There are examples on the foregoing activities in different parts of Africa. For instance, Nigeria has a range of western oil companies, such as Mobil, Texaco, Agip, Chevron, Exxon and Royal Dutch/Shell that hold oil production licences in the Niger Delta, one of the biggest wetlands in the world. Of all these companies, Shell Nigeria, a subsidiary of Royal Dutch/Shell, was the first to discover oil in Ogoniland, Niger Delta area (Hennchen 2015). Persistent oil and gas flaring in Ogoniland does not only contribute to climate change as it means the releases of carbon dioxide underlying global warming into the atmosphere (Bruckner et al. 2014, p. 522; UN 2006). Its associated effects including the pollution of the ecosystem and devastation of the land, water and air cause displacement of populations and importantly children in Ogoni land (UNHRC 2018).

The implementation of the project that aimed to address climate change by promoting alternative energy also causes displacement of children. For instance, the involvement of Londonbased Central African Mining and Exploration Company (CAMEC) in a large bio-ethanol project, called Procan, plays a significant role in the dispossession and displacement of populations including children in Central and Southern Africa (Vermeulen and Cotula 2010). Overall, the conduct or omission of state-owned corporations by Africa in other African states and the conduct or omission of foreign companies of the North in Africa may result in the displacement which involves children in Africa. The next section considers the likely implications of this displacement for broader socio-economic rights of children in Africa.

\section{Extraterritorial climate displacement as a violation of socio-economic rights of children}

Although not yet applied extraterritorially, the instruments in the African human rights system seek to protect the socio-economic rights of children through the provisions of the ACRWC (1990), the African Charter (OAU 1986), and the Kampala Convention (2009), the latter being relevant in the context of climate change and displacement. The provisions of these instruments are instructive on socio-economic rights linkage to displacement and are further illuminated by the decisions of treaty monitoring bodies at the African regional level, notably, the CERWC and the African Commission. Both monitoring bodies apply international human rights instruments under the United Nations, through Article 60 of the African Charter (OAU 1986) and Article 46 of the ACERW (1990) which empowers them respectively to draw inspirations from international human rights instruments. The treaty monitoring bodies within the African human rights system has handled matters of significance to socio-economic rights, foreign non-state actors and displacement of children. In Institute for Human Rights and Development and Others $v$. Democratic Republic of Congo (ACHPR 2016, Kilwa case), the African Commission noted that the displacement of populations including children and the destruction of the socio-economic infrastructure such as the schools, hospital and other structures can be linked to activities of foreign-owned companies operating in Africa. Hence, it condemned the atrocious involvement 
of corporations (particularly Anvil mining, Australia) in the violations of rights and gave clear directions as to the minimum obligation on companies not to actively violate or support the violation of human rights in Africa. Understandably, it is difficult to find a violation of extraterritorial obligations as neither Australia (Developed state) nor Anvil mining (non-state actor) is party to the African Charter or other instruments in the African human rights system.

Also, the decision of CERWC in Michelo Hansungule and others (on behalf of Children in Northern Uganda) v. the Government of Uganda (Children of Northern Uganda case) (ACHPR 2013) is instructive on the general effects of displacement on children's rights. In that case, the CERWC establishes the link between massive displacement and gross violations of human rights including children's rights (ACHPR 2013, paras. 2, 3 and 7). In doing so, it found their displacement a violation of Article 1(1) of the ACRWC (ACHPR 2013, para. 37) which requires states in Africa to adopt legislative and other measures for the recognition rights, freedoms and duties enshrined in the instrument (ACHPR 2013, para. 37).

Arguably, climate-induced displacement of children can infringe a range of socio-economic rights of children. Rights of children are indivisibly linked, but activities of actors underlying climatic problems trigger several distressing events that separate them from friends and family members. Even when families stay together, the difficulties they face in establishing a degree of security and community solidarity affects them and pose a general threat to Article 18 of the ACRWC (1990) on the right to children to parental care and protection. Such activities also have implications on the right to health, the right to education and culture, the right to water and the right to food of children in Africa.

All said, the extraterritorial link of climate change to displacement infringes a range of socioeconomic rights of the child, namely, the right to health, the right to education and culture, the right to water and the right to food of children in Africa. It remains to be seen the extraterritorial potentials within the African human rights system that may apply to respond to climateinduced displacement and its impact on socio-economic rights of children in Africa.

\section{Potentials for extraterritorial response to climate-induced displacement of children}

Generally, the protection of human rights is territorial (Kanalan 2018), but recent writings argue the possibility of extraterritorial application of economic and social cultural rights guaranteed in key UN human rights instruments (Vandenhole 2020; Skogly 2013; Coomans 2011) and their relevance to the children's rights protection regime (Vandenhole 2020; Vandenhole 2009). For instance, Coomans (2011) explains that the International Covenant on Economic, Social and Cultural Rights (ICESCR) has extraterritorial dimension in that its treaty monitoring body, the CESCR Committee, calls upon states to seek foreign assistance in fulfilling socio-economic responsibilities (CESCR General Comment no. 22, paras. 50-52). Using UN General Comment no. 19 on public budgeting resources to fully realise the CRC (CRC Committee General Comment no. 19) as an example, Vandenhole (2020, p. 227) clarifies that the interpretation of the Committee on the Rights of the Child regarding extraterritorial application of the CRC is in line with that of the CESCR.

Triggers for the application of extraterritorial fulfilment of human rights include the causation of human rights harm (Skogly 2013), and historical responsibility (Vandenhole 2020; Vandenhole and Benedek 2013). The latter point is in fact instructive as it is the basis for the principle of common but differentiated responsibility which is entrenched in Articles 3(1) and 4(1) of the UNFCCC (1992), Article 10 of the Kyoto Protocol (2005) and Article 2(2) of the Paris Agreement (2015) to ensure fairness and equity between the North and South in the 
global response to climate change (Wang and Gao 2018). It also agrees with the 'polluters pay principle', which traces responsibility to address environmental change to those who are responsible for its cause (Luppi, Parisi and Rajagopalan 2012; Rio Declaration 1992, principle 16). Addressing causation linked to activities of North is problematic, although attribution science is developing and making it possible to address causation challenges by linking a company's conduct to climate harm. This is done by establishing: (a) the association between greenhouse gas emissions and meteorological change; and (b) the relationship between meteorological change and societal impacts (McCormick et al. 2018). Hence, it may be possible to be able to link a company's conduct with a particular climate harm even if only partially (McCormick et al. 2018).

At the African regional level, the possibilities of extraterritorial application of key instruments have also been subject of scholarship. With respect to the African Charter,Viljoen (2008, p. 107) notes that accountability is possible where 'an extraterritorial incident or even in cases where the state has de facto control over that incident or event'. On the same instrument, Bulto (2011, p. 523) argues that there is 'no textual basis to limit the spatial reach of socio-economic rights such as the right to water or correlative state obligations to a state's territorial jurisdiction'. In a number of his writings, Jegede $(2017 ; 2016)$ argues that key African regional human rights instruments including the Kampala Convention may apply extraterritorially in the context of climate-induced displacement of indigenous peoples. Regarding obligations of states towards children, General Comment no. 5 of the CERWC (2018) generally discusses the obligations of states in Africa in strengthening the protection of the rights of the child. Using the instruments that constitute children rights regime under the $\mathrm{AU}$ as a basis of analysis, this section argues that extraterritorial responsibility for climate-induced displacement of children is possible on two grounds: extraterritorial application of obligations among states in Africa; and obligations applicable to developed states outside Africa.

\section{Extraterritorial obligations among states towards children in Africa}

According to the General Comment no. 5 of the CERWC (2018, para. 3.5), the core and universally accepted obligations to 'respect', 'protect', 'promote' and 'fulfil' children's rights apply to the implementation of the ACRWC as a whole. These obligations agree with the Kampala Convention (2009, preamble), and the African Charter (1986) as discernible from the jurisprudence of the African Commission in the Ogoniland case (para. 45). It is also supported by the provisions of Maastricht Principles (2011, p. 3) on extraterritorial obligations of states representing international expert opinion that clarifies states obligations under international human rights law. The principles are applicable as part of the children's rights regime in Africa by virtue of Article 61 of the African Charter (1986) and Article 46 of the ACERWC (1990) which allow the monitoring bodies of these respective instruments to draw inspiration from international human rights law.

That the provisions of AU human rights instruments are applicable extraterritorially among states in Africa is not farfetched. Article 1 of the ACRWC (1990), which speaks to obligations of states, is not territorial in nature. Rather, it calls upon states to recognise all the rights and duties entrenched in the instrument and takes needful measures to ensure its realisation. Besides, the extraterritorial application of these instruments to climate-induced displacement of children is in the best interest of the child in Africa. Article 4(1) of the ACRWC (1990) establishes that 'in all actions undertaken by any person or authority, the best interests of the child shall be the primary consideration'. It is in the best interest of the child to require actors responsible for climateinduced displacement to contribute towards its solution whether they are based within or outside the territory of its occurrence. This reasoning is consistent with General Comment no. 5 of the 
CERWC (2018, para. 4.2) which dismisses the idea that there can be any conditions that could thin the scope, reach or standard of the application of the principle of the best interest of the child. Interestingly, General Comment no. 5 of the CERWC (2018, para. 4.2) also requires 'private actors, including parents, institutions, business entities and various non-state actors engaged with children's rights and services' to adopt the principle of the best interest of the child in all endeavours. Hence, considering that private and non-state actors are involved in activities triggering the climate change scenarios that drive displacement of children, it is legally plausible to construe that extraterritorial obligations exist among states in Africa to 'respect', 'protect', 'promote' and 'fulfil' rights as a response to climate-induced displacement of children in Africa.

The obligation to 'respect' connotes that states should not interfere in the enjoyment of rights of collective groups (ACHPR 2001, para. 45). The Maastricht Principles (2011, Principles 29-35), De Schutter et al (2012, pp. 1126-1133) indicate that the extraterritorial obligation to 'respect' requires states to refrain from direct conduct which may hinder the realisation of rights outside their territories. Articles 3(1)(a), (d) \& 4(1) of the Kampala Convention (2009) reflect obligations to 'respect' children rights in the context of displacement where it requires state parties to 'refrain from, prohibit and prevent arbitrary displacement of populations'. In the situation of climate-induced displacement and children, the extraterritorial application of the obligation to 'respect' signifies that no state in Africa should, through its agents, be involved in climate response projects in a manner that brings about the displacement of children in another African state. It demands that where involvement in such projects is inevitable, the best interest of the child should be a consideration.

The obligation to 'protect', according to the African Commission, requires states to adopt measures such as legislation and to provide effective remedies for the protection of rights holders 'against political, economic and social interferences' and to control non-state actors so that their operations do not hamper rights (ACHPR 2001, para. 46). This position resonates with the Maastricht Principles (2011) which require states to ensure through appropriate legislation that their non-state actors do not hinder rights abroad. Where states cannot regulate their conduct, they should at the very least influence the conduct of non-state actors and cooperate to ensure that rights are not impeded extraterritorially by non-state actors. To children at risk of climate-induced displacement, this means states should put in place a mix of laws and regulations so that their rights are not impeded due to climate change but protected. Also, it means that states should seek to apply existing legislation and regulation in such a manner that children imperilled by climate-induced displacement are offered adequate assistance.

The obligation to 'fulfil' requires states to mobilise 'its machinery towards the actual realisation of the rights' (ACHPR 2001, para. 47). It includes the provision of 'basic needs such as food or resources that can be used for food'. The Maastricht Principles specify that the extraterritorial implication of the obligation to 'fulfil' involves cooperation, request and response to international assistance. In relation to obligation to cooperate, Article 8(3)(d) tasks the AU to cooperate with African states and other actors for protecting and assisting displaced persons. The General Comment no. 5 of the CERWC (2018, para. 7.2) calls upon states to cooperate with AU structures, as well as with national and international partners, to discourage practices that are incompatible with the ACERWC. Arguably, this cooperation can be in form of relaxing asylum-seeking rules and expediting the asylum-seeking applications where children are involved. For instance, one would expect an African state whose non-state actor is known for activities responsible for displacement of children in another state in Africa to be obliged to accept asylum-seeking applications involving children from states where their corporations operate. Doing so is not based on moral guilt but on the best interest of children to enable children, and by implication, their care givers settle quickly, and access resources required for the welfare and upbringing in foreign African states. 
The obligation to fulfil also involves assistance. Article 20 (2)(a) of the ACRWC (1990) urges state parties to provide material support and assistance. Along similar lines, Article 3(2)(d) of the Kampala Convention (2009) urges state parties to make available, as far as possible, the necessary funds and seek international support for protecting displaced persons in Africa. Article 9(2)(b) of the same instrument reinforces that the assistance includes the provision of food, water, shelter and medical care for their necessary protection. Also, at least states from which corporations whose climate-related activities occasion displacement originate should be willing to assist in making these essential provisions possible. Where unable to provide, they should lead or support the request for international assistance either within or outside Africa. In line with this obligation, states in Africa can seek assistance from one another in responding to climate-induced displacement of children in Africa. Also, based on the vulnerability of children, assistance that addresses pressing needs such as food shelter and water should be a matter of priority.

The obligation to 'promote' the enjoyment of all human rights entails that state parties should ensure 'that individuals are able to exercise their rights, for example, by promoting tolerance, raising awareness, and even building infrastructures' (ACHPR 2001, para. 46). Its extraterritorial connotation is explained by the Maastricht Principles (2011) to include the observance of principles such as informed participation (Principle 7), and impact assessment (Principle 14). This obligation is evident in the provisions of Articles 10(2) and 10(3) of the Kampala Convention (2009) that aim at promoting consultation and participation of displayed persons in decision-making and the socio-economic and environmental impact assessment of projects related to development. While these provisions generally relate to displaced persons, it applies to the specific circumstance of children confronted by climate-induced displacement. Its application requires that states with actors operating in other states in Africa should ensure that such actors engage children in participation, assess climate-related projects in terms of their potential impacts of children and embark on programmes and activities that strengthen and do not undermine the best interest of children. Doing so may help in averting displacement and its harmful consequences on the socio-economic rights of children in Africa.

\section{Role of developed states towards climate-displaced children in Africa}

There are provisions in the children's rights protection regime of Africa that justify a proposition that developed states, in particular, those whose non-state actors are at the heart of climaterelated displacement, have a role to play for extraterritorial conduct or omission underlying the climate-induced displacement of children. Article 20 (2)(a) of the ACRWC (1990) urges state parties to provide material support and assistance but does not foreclose assistance from states outside Africa. Also, Article 8(3)(b) of the Kampala Convention (1990), which requires the AU to 'co-ordinate mobilisation of international resources for the assistance and protection' for displaced persons, can be applied to mobilise funds in support of children displaced by climate change. To fulfil the role, emphasis is placed in Article 8(3)(c) of the Kampala Convention on 'collaboration with international organisations and humanitarian agencies, civil society organisations and other relevant actors' to support concerned state parties. The fact that these provisions highlight the relevance of 'international organisations and humanitarian agencies, civil society organisations and other actors', without limiting this to Africa, suggests that states in Africa can reach for international support beyond Africa for children displaced due to climate change.

Where the above provisions in the children rights regime of the African human rights system are activated, developed countries in the North, even if not state parties to the instruments, should be obligated to support displaced children outside the accountability framework of the African human rights system. One reason is that the operations of foreign companies can be 
linked to displacement and violations of rights as seen in the Kilwa case. Another reason in support of such an expectation is that attribution science can help in linking causation of displacement of children with climate-related activities of companies from the North. Yet another reason is the necessity for 'colonial justice' which, according to Wilde (2020, p. 58), speaks to 'the environmentally harmful basis on which the economically privileged parts of the world attained this privilege'. The latter resonates loudly with Africa's tragic historical experience of colonialism and marginal contribution of the continent to the present state of the climate. Besides, within the pillar instruments on climate change, there are grounds to expect that the request and response to such assistance extend to developed states outside Africa. Developed states under the climate change related instruments, in particular, Article 4(1)(b) of the UNFCCC (1992) and Article 9 of the Paris Agreement (2015) have greater commitment to provide different forms of assistance, including the promotion, facilitation and provision of finances and appropriate technology, practices and processes to address the adverse effect of climate change in developing states, including Africa.

In the context of Africa and reference to children displaced by climate change, international organisations and humanitarian agencies should be willing to facilitate how children so displaced may be helped to settle down and access amenities in their newly found places or states, and thereby ensure that their socio-economic rights are not denied. This reasoning is supported by the Maastricht Principles (2011), which recognise the role of international assistance and cooperation of organisations and humanitarian agencies, civil society organisations and other actors (De Schutter et al 2012, p. 1104). Hence, regarding climate-induced displacement of children, states can request the $\mathrm{AU}$ as an entity to use its platforms of engagement to mobilise international resources for the assistance and resources required to address the climate-related displacement of children in Africa. States in Africa can also assist one another to take care for children migrants displaced by climate change to ensure that their socio-economic rights are protected.

\section{Conclusion}

Displacement linked to climate affects all mankind but its impact on children in Africa is peculiar due to their vulnerability and the risk which it poses to a range of their socio-economic rights. This chapter interrogates whether extraterritorial link of climate change to displacement of children exists, and if so, how it affects their socio-economic rights as well as the manner through which ETOs can be deployed as a response to its effect on socio-economic rights of children in Africa. As has been demonstrated, on the one hand, climate change is linked to displacement of children through the conduct or omission of an African state or its actors in and outside its territory in Africa. On the other hand, it is connected by means of the conduct or omission of actors from the developed North in their territories and in states within Africa. The failure of a state to address the extraterritorial reach of activities underlying climate change and actions relating to climate change response may have implications on the right to property, the right to health, the right to education and culture, the right to water and the right to food of children in Africa. To adequately respond to this risk to key socio-economic rights, states in Africa can among themselves apply obligations to 'respect', 'protect', 'promote' and 'fulfil' rights as a response to climate-induced displacement of children in Africa. Also, there are provisions dealing with international cooperation and assistance in key human rights instruments of the African human rights system that support the position that developed states have a role to play in response to the implications of extraterritorial conduct or omission underlying the climateinduced displacement of children in Africa. 


\section{References}

African Charter on the Rights and Welfare of the Child (ACERW) (2018) GC 5 on State Party Obligations under the African Charter on the Rights and Welfare of the Child (Article 1) and Systems Strengthening for Child Protection.

African Charter on the Rights and Welfare of the Child (ACRWC) (1990) OAU Doc. CAB/LEG/24.9/49. African (Banjul) Charter on Human and Peoples' Rights (1982) OAU Doc. CAB/LEG/67/3 rev. 5, 21 I.L.M. 58 .

African Commission on Human and Peoples' Rights (ACHPR) (1995) Free Legal Assistance Group and Others v. Zaire, AHRLR 74.

(2001) Social and Economic Rights Action Centre (SERAC) \& Another v. Nigeria, AHRLR 60.

(2009a) Resolution on climate change and human rights and the need to study its impact in Africa, ACHPR/Res153(XLVI)09.

(2009b) Sudan Human Rights Organization \& Centre for Housing Rights and Evictions v. Sudan, Communication 279/03 and 296/05.

(2012) Resolution 231 on the right to adequate housing and protection from forced evictions, adopted at the 52nd ordinary session of the held in Yamoussoukro, Côte d'Ivoire.

(2013) Michelo Hansungule and others (on behalf of Children in Northern Uganda) v. the Government of Uganda, Communication 1/2005.

(2015) The Nubian Community in Kenya vs The Republic of Kenya, Communication 317/2006.

(2016) Institute for Human Rights and Development and Others v. Democratic Republic of Congo, Communication 393/10.

(2019) 'Background Study on the Operations of the Extractive Industries Sector in Africa and its Impacts on the Realisation of Human and Peoples' Rights under the African Charter on Human and Peoples' Rights', https://www.achpr.org/public/Document/file/English/Background\%20Study\%20 on $\% 20$ the $\% 20$ Operations $\% 20$ of $\% 20$ the $\% 20$ Extractive $\% 20$ Industries $\% 20$ Sector $\% 20 \mathrm{in} \% 20$ Africa_ ENG.pdf [accessed 8 October 2020].

African Committee of Experts on the Rights and Welfare of the Child (2014) Centre for Human Rights and Rencontre Africaine pour la Défense des Droits de l'Homme v. Senegal, Communication 003/12.

African Union (2009) Convention for the Protection and Assistance of Internally Displaced Persons in Africa, 'Kampala Convention'.

AU Press (2020) 'Press Statement on the Occasion of the 33rd Assembly of the Heads of State and Government of the African Union', Addis Ababa Ethiopia.

BBC (2019) 'How Africa will be Affected by Climate Change', https://www.bbc.com/news/worldafrica-50726701 [accessed 8 October 2020].

Boko, M.I. et al. (2007) 'Africa' in Parry, M.L. et al. (eds). Climate Change, Impacts, Adaptation and Vulnerability, Contribution of Working Group II to the Fourth Assessment Report of the Intergovernmental Panel on Climate Change, Cambridge University Press.

Bongaarts, J. and O'Neill, B. (2018) 'Global Warming Policy: Is Population Left Out in the Cold?', Science 361(6403), 650-652.

Bruckner, T. et al. (2014) 'Energy Systems' in Edenhofer, O.R. et al. (eds.). Climate Change 2014: Mitigation of Climate Change. Contribution of Working Group III to the Fifth Assessment Report of the Intergovernmental Panel on Climate Change, Cambridge University Press.

Bulto, T.S. (2011) 'Towards Rights-Duties Congruence: Extraterritorial Application of the Human Right to Water in the African Human Rights System', Netherlands Quarterly Human Rights 29(4), 491-523.

Burck, J. et al. (2019) 'Climate Change Performance Index: Results', https://germanwatch.org/sites/ germanwatch.org/files/CCPI2019_Results.pdf [accessed 8 October 2020].

Colangelo, A.J. (2014) 'What is Extraterritorial Jurisdiction?', Cornell Law Review 99, 1303-1352.

Committee on Economic, Social, and Cultural Rights (CESCR) (2016) GC 22 on the right to sexual and reproductive health (article 12 of the International Covenant on Economic, Social and Cultural Rights), UN Doc E/C.12/GC/22. 
Committee on the Rights of the Child (CRC Committee) (2013) GC 15 on the right of the child to the enjoyment of the highest attainable standard of health, $\mathrm{CRC} / \mathrm{C} / \mathrm{GC} / 15$. GC/19.

(2016) GC 19 on public budgeting for the realization of children's rights (art. 4), CRC/C/

Convention on the Rights of the Child (1989) U.N.T.S. vol. 1577.

Concord Times (2020) 'Sierra Leone's Electricity Development Partner Appointed Energy Minister in Tunisia', http://slconcordtimes.com/sierra-leones-electricity-development-partner-appointed-energyminister-in-tunisia/ [accessed 8 October 2020].

De Schutter, O. et al. (2012) 'Commentary to the Maastricht Principles on Extraterritorial Obligations of States in the Area of Economic Social and Cultural Rights', Human Rights Quarterly 34(4), 1084-1169.

ETO Consortium, 'Maastricht Principles on Extraterritorial Obligations of States in the Area of Economic, Social and Cultural Rights', https://www.etoconsortium.org/nc/en/main-navigation/library/ maastricht-principles/?tx_drblob_pi1\%5BdownloadUid\%5D=23 [accessed 8 October 2020].

Globeleq (2015) 'Sasol Natural Gas Project Resettlement Planning and Implementation Programme Addendum 15 - Mozambique Gas to Power Plant (MGtP) Interim Report', Globeleq

Gorte, R.W. and Sheikh, P.A. (2010) Deforestation and climate change, CRS Report for Congress.

Greenpeace (2010) 'Left in the Dust:AREVA's Radioactive Legacy in the Desert Towns of Niger', https:// www.sortirdunucleaire.org/IMG/pdf/greenpeace-2010-left_in_the_dust-areva_s_radioactive_legacy_ in_the_desert_towns_of_niger.pdf [accessed 8 October 2020].

Hennchen, E. (2015) 'Royal Dutch Shell in Nigeria:Where Do Responsibilities End?', Journal of Business Ethics 129(1), 1-25.

IBRD and World Bank World Development Report (2010) Development and climate change, World Bank.

Intergovernmental Panel on Climate Change (IPCC) (2014) Climate Change 2014: Impacts, Adaptation, and Vulnerability. Summary for Policymakers. Contribution of Working Group II to the Fifth Assessment Report of the Intergovernmental Panel on Climate Change, IPCC.

(2018) 'Summary for Policymakers' in Masson-Delmotte, V. et al. (eds). Global Warming of $1.5^{\circ} \mathrm{C}$. An IPCC Special Report on the Impacts of Global Warming of $1.5^{\circ} \mathrm{C}$ Above Pre-Industrial Levels and related Global Greenhouse Gas Emission Pathways, in the context of Strengthening the Global Response to the Threat of Climate Change, Sustainable Development, and Efforts to eradicate Poverty, Cambridge University Press.

International Covenant on Economic, Social and Cultural Rights (ICESCR)

Jegede, A.O. (2016) 'Rights Away from Home: Climate-Induced Displacement of Indigenous Peoples and the Extraterritorial Application of the Kampala Convention', African Human Rights Law Journal 16(1), $58-82$.

Jegede, A.O. (2017) 'The Protection of Indigenous Peoples' Lands by Domestic Legislation on Climate Change Response Measures: Exploring Potentials in the Regional Human Rights System of Africa', International Journal on Minority and Group Rights 24(1), 24-56.

Kanalan, I. (2018) 'Extraterritorial State Obligations Beyond the Concept of Jurisdiction', German Law Journal 19(1), 44-63.

Luppi, B., Parisi, F. and Rajagopalan S. (2012) 'The Rise and Fall of the Polluter-pays Principle in Developing Countries', International Review of Law and Economics 32(1), 135-144.

Mbaye, A.A. (2020) 'Confronting the Challenges of Climate Change on Africa's Coastal Areas', https:// www.brookings.edu/blog/africa-in-focus/2020/01/16/confronting-the-challenges-of-climatechange-on-africas-coastal-areas/ [accessed 8 October 2020].

McCormick, S. et al. (2018) 'Strategies in and Outcomes of Climate Change Litigation in the United States', Nature Climate Change 8, 829-833.

Mckibben, B. (2003) The End of Nature: Humanity, Climate Change and the Natural World, Random House Trade Books.

Mineral Council South Africa (2019) Facts and Figures Pocketbook, Mineral Council South Africa.

Mutua, M. (2000) 'The African Human Rights System:A Critical Evaluation', https://digitalcommons.law. buffalo.edu/other_scholarship/16/ [21 July 2021].

Palmer, P.I. et al. (2019) 'Net Carbon Emissions from African Biosphere dominate Pan-tropical Atmospheric CO2 Signal', Nature Communication 10, 1-9. 
Paris Agreement under the United Nations Framework Convention on Climate Change (2015) adopted 30 Nov.- 11 Dec. 2015 at the 21st Sess., Conference of the Parties, FCCC/CP/2015/L.9/Rev.1

Pfefferbaum, B. et al. (2016) 'Effects of Displacement in Children Exposed to Disasters', Current Psychiatry Reports $18(8), 71$.

REG (2019) 'Plant Design, Supply, and Installation of Low Voltage and Medium Voltage Lines and Service Connections in the Huye, Nyamagabe, Nyanza, Kamonyi and Ruhango Districts, Southern Province of Rwanda contract agreement $N^{\circ}$ 11.07.023/1256/19/EDCL-MD/FG/cm', https://www.reg. rw/fileadmin/user_upload/ESMP_STEG_IS_Project_Southern_province.pdf [accessed 8 October 2020].

Skogly, S. (2013) 'Causality and Extraterritorial Human Rights Obligations' in Langford, M. et al. (eds). Global Justice, State Duties: the Extraterritorial Scope of Economic, Social and Cultural Rights in International Law, Cambridge University Press.

The Carbon Brief Profile (2018) 'South Africa', https://www.carbonbrief.org/the-carbon-brief-profilesouth-africa [accessed 8 October 2020].

Toulmin, C. (2009) Climate Change in Africa, Zed Books. United Nations (UN) (1991) GC 4 on the right to adequate housing, art. 11(1) of the Covenant, 6th session.

UN (1997) GC 7 on the right to adequate housing, art .11(1) of the Covenant: Forced evictions 16th session.

UN (1998) Kyoto Protocol to the United Nations Framework Convention on Climate Change.

UN (2020) 'Climate change', https://www.un.org/en/sections/issues-depth/climate-change [accessed 8 October 2020].

United Nations Framework Convention on Climate Change (UNFCCC) (n.d.) 'The impact of climate change on the rights of the child', https://www.ohchr.org/EN/Issues/HRAndClimateChange/Pages/ RightsChild.aspx [accessed 8 October 2020].

United Nations International Children's Emergency Fund (UNICEF) (2003) ‘Displaced children', https:// www.unicef.org/emergencies/index_displacedchildren.html [accessed 8 October 2020].

(2016) 'Collecting water is often a colossal waste of time for women and girls', https://www. unicef.org/press-releases/unicef-collecting-water-often-colossal-waste-time-women-and-girls [accessed 8 October 2020].

(2018) 'Around 30 million children displaced by conflict need protection now and sustainable solutions over the long term', https://www.unicef.org/press-releases/around-30-million-children-displaced-conflict-need-protection-now-and-sustainable [accessed 8 October 2020].

United Nations Office of the High Commissioner for Human Rights (UNHCR) (2018) 'Summary of Stakeholders' submissions on Nigeria. Report of the Office of the United Nations High Commissioner for Human Rights', https://digitallibrary.un.org/record/1643075/files/A_HRC_WG-6_31_NGA_3EN.pdf. [accessed 8 October 2020].

(2019) 'Global Trends Forced Displacement in 2019', https://www.unhcr.org/5ee200e37.pdf [accessed 8 October 2020].

United Nations General Assembly (1988) Protection of global climate for present and future generations of mankind, 70th plenary meeting, UNGA Res 43/53.

United Nations High Commissioner for Human Rights (2018) Summary of Stakeholders' submissions on Nigeria, A/HRC/WG.6/31/NGA/3 24.

United Nations Human Rights Council (2014) Resolution 26 L/33 - Human rights and climate change, A/HRC/26/L.33.

Vandenhole, W. (2009) 'Economic, Social and Cultural Rights in the CRC: Is there a Legal Obligation to Cooperate Internationally for Development?', International Journal of Children's Rights 17, 23-63.

(2020) 'Towards a Division of Labour for Sustainable Development: Extraterritorial Human Rights Obligations' in Kaltenborn, M., Krajewski, M. and Kulin, H. (eds.). Sustainable Development Goals and Human Rights, Interdisciplinary Studies in Human Rights, Springer Cham.

Vandenhole, W. and Benedek, W. (2013) 'Extraterritorial Human Rights Obligations and the North-South Divide' in Langford, M. et al. (eds.). Global Justice, State Duties:The Extraterritorial scope of Economic, Social and Cultural Rights in International Law, Cambridge University Press. 
Vermeulen, S. and Cotula, L. (2010) 'Over the Heads of Local People: Consultation, Consent, and Recompense in Large-Scale Land Deals for Biofuels Projects in Africa', Journal of Peasant Studies 37(4), 899-916.

Viljoen, F. (2008) 'Communications under the African Charter: Procedure and Admissibility' in Evans, M. and Murray, R. (eds.). The African Charter on Human and Peoples' Rights: The System in Practice 1986-2006, 2nd ed., Cambridge University Press.

Wang, T. and Gao, X. (2018) 'Reflection and Operationalization of the Common but Differentiated Responsibilities and Respective Capabilities Principle in the Transparency Framework under the International Climate Change Regime', Advances in Climate Change Research 9, 253-263.

Wilde, R. (2020) 'Pursuing Global Socio-Economic, Colonial and Environmental Justice through Economic Redistribution: The Potential Significance of Human Rights Treaty Obligations' in Bander, C. et al. (eds.). Research Handbook on International Law and Social Rights, Edward Elgar.

World Bank (2018) Groundswell: Preparing for Internal Climate Migration, The World Bank.

World Data Atlas (2018a) 'Nigeria - CO2 emissions', https://knoema.com/atlas/Nigeria/CO2-emissions [accessed 8 October 2020].

World Data Atlas (2018b) 'Democratic Republic of the Congo - CO2 emissions', https://knoema.com/ atlas/Democratic-Republic-of-the-Congo/CO2-emissions [accessed 8 October 2020].

Y Charts (2020) 'Egypt. Carbon Dioxide Emissions', https://ycharts.com/indicators/egypt_carbon_dioxide_emissions [accessed 8 October 2020]. 